\title{
Potentiometric and pHmetric Studies of Paracetamol
}

\section{Swaroopa Rani N Gupta*}

Department of Chemistry, Brijlal Biyani Science College, Amravati, Maharashtra, India

\begin{abstract}
Acid-base titration of paracetamol in nonaqueous solvents was done. Procedure was followed for titration of paracetamol in different media like acetic acid, pyridine, dimethlformamide and ethyl alcohol with standard perchloric acid in glacial acetic acid, sodium ethoxide in ethyl alcohol using plantinum-calomel as well as glass-calomel electrode system. The equivalence point was located as accurately as possible by a differential graph of $\Delta \mathrm{E} / \Delta \mathrm{V}$ or $\Delta \mathrm{pH} / \Delta \mathrm{V}$ against $\mathrm{V}$ and concentration of test solution was computed.

The acid-base titration of paracetamol is rapid and reproducible, and permits its determination in medicinal sample. The electrode systems vary with the solvent employed. The platinum-calomel electrode system is suitable where the solvent is glacial acetic acid in this case perchloric acid in glacial acetic acid is the titrant while the glass-calomel electrode system is suitable where the solvent is either pyridine, an alcohol or dimethyiformamide, the titrant consists of sodium ethoxide in ethyl alcohol.
\end{abstract}

Keywords: Acetic acid; Dimethlformamide; Ethyl alcohol; Paracetamol; Pyridine

\section{Introduction}

Paracetamol (acetaminophen) is one of the most popular analgesic and antipyretic drugs. Paracetamol is available in different dosage forms: tablet, capsules, drops, elixirs, suspensions and suppositories. Dosage forms of paracetamol and its combinations with other drugs have been listed in various pharmacopoeias [1,2]. The combination of paracetamol with dipyrone is used as an antipyretic, analgesic and anti-inflammatory drug. Numerous methods have been reported for the analysis of paracetamol and its combinations in pharmaceuticals or in biological fluids. Paracetamol has been determined in combination with other drugs using titrimetry [3,4], voltammetry [5], fluorimetry [6], colorimetry [6], UV-spectrophotometry [7-9], quantitative thin-layer chromatography (TLC) [10], high-performance liquid chromatography (HPLC) [11-16] and gas chromatography (GC) [17] in pharmaceutical preparations. Effect of electrophilic and electrodotic groups on the potentiometric titration of amides and other weak bases was studied [18]. Electrodotic groups enhance the potentiometric end point and electrophilic groups depress it, sometimes to the extent that the compound is not titratable. A combination of chloroform and acetic anhydride is a useful alternative medium for the titration of weak bases. A potentiometric method for determination of $\mathrm{p}$-acetamidophenol was reported [19].

Analytical data are given for a representative number of amides, acetylated amines, and formylated amines [20]. In acetic acid, amides show little tendency toward salt formation with $\mathrm{CH}_{3} \mathrm{COOH}_{2}^{+}$; however, upon addition of acetic anhydride, additional acidic species become evident and measurable end points are observed [21].

$\mathrm{CH}_{3} \mathrm{COOH}_{2}^{+}+\left(\mathrm{CH}_{3} \mathrm{CO}\right)_{2} \mathrm{O} \leftrightarrows\left(\mathrm{CH}_{3} \mathrm{CO}\right)_{2}-\mathrm{OH}^{+}+\mathrm{CH}_{3} \mathrm{COOH} \leftrightarrows$ $\mathrm{CH}_{3} \mathrm{CO}^{+}+\left(\mathrm{CH}_{3} \mathrm{COOH}\right)_{2}$

Considerable evidence for this equilibrium has been presented by a number of investigators [21-25].

An accurate, simple, reproducible and sensitive method for the determination of paracetamol, caffeine and dipyrone was developed and validated [26].

In present study acid-base titration of paracetamol in nonaqueous solvents was done. Procedure was followed for titration of paracetamol in different media like acetic acid, pyridine, dimethlformamide and ethyl alcohol with standard perchloric acid in glacial acetic acid, sodium ethoxide in ethyl alcohol using plantinum-calomel as well as glass-calomel electrode system. The equivalence point was located as accurately as possible by a differential graph of $\Delta \mathrm{E} / \Delta \mathrm{V}$ or $\Delta \mathrm{H} / \Delta \mathrm{V}$ against $\mathrm{V}$ and concentration of test solution was computed.

\section{Methodology}

All chemicals were of A.R. grade. Solvents were purified before use. Medicinal samples of paracetamol were collected from local market of different make. OSAW direct reading potentiometer was used to carry out redox titrations using bright platinum wire and saturated calomel electrodes. The $\mathrm{pH}$-titrations were made with an ELICO LI$10 \mathrm{pH}-$ meter in conjuction with Glass (EM-42) and calomel (ER-70) electrodes.

Acid-base titration of paracetamol in nonaqueous solvents was done by taking $0.2 \mathrm{~g}$ of Crocin paracetamol (Duphar) tablet in a 250 $\mathrm{ml}$ beaker and was dissolved in $25 \mathrm{ml}$ of glacial acetic acid. A bright platinum wire electrode was dipped; the solution was connected to a calomel electrode via salt bridge and titrated with $0.1 \mathrm{~N}$ perchloric acid in acetic acid. Similar procedure was followed for titration of paracetamol in other media like pyridine, dimethlformamide and ethyl alcohol with standard sodium ethoxide in ethyl alcohol using plantinum-calomel as well as glass-calomel electrode system. The equivalence point was located as accurately as possible by a differential graph of $\Delta \mathrm{E} / \Delta \mathrm{V}$ or $\Delta \mathrm{H} / \Delta \mathrm{V}$ against $\mathrm{V}$ and concentration of test solution was computed.

\section{Observation}

Potentiometric methods embrace two major types of analyses: the direct measurement of an electrode potential from which the concentration of an active ion may be derived, and the changes in the electromotive force of an electrolytic cell brought about through the

*Corresponding author: Swaroopa Rani N. Gupta, Department of Chemistry, Brijlal Biyani Science College, Amravati, Maharashtra, India, Tel: +919665041291; E-mail: swargupta@yahoo.com

Received January 11, 2015; Accepted January 23, 2016; Published January 25 2016

Citation: Gupta SRN (2016) Potentiometric and pHmetric Studies of Paracetamol. Med chem 6: 047-052. doi:10.4172/2161-0444.1000323

Copyright: (c) 2016 Gupta SRN. This is an open-access article distributed under the terms of the Creative Commons Attribution License, which permits unrestricted use, distribution, and reproduction in any medium, provided the original author and source are credited. 
addition of a titrant. Two types of potentiometric titrations, OxidationReduction and Acid-Base titrations in nonaqueous solvents, have been performed, and interest is focused upon changes in the e.m.f. of an electrolytic cell as a titrant of precisely known concentration is added to a solution of the analyte namely paracetamol.

Acid-base titration data for paracetamol against perchloric acid and $\mathrm{C}_{2} \mathrm{H}_{2} \mathrm{ONa}$ in different media - glacial acetic acid, pyridine, dimethyl formamide and ethyl alcohol are shown in Table 1.

An end point is located more precisely by plotting successive values of the rate of change of cell e.m.f. vs each increment of titrant in the vicinity of the inflection point. The position of the maximum on the first derivative curve, Figures 1-6 corresponds to the inflection point on the normal titration curve.

\section{Results and Discussion}

The results of estimation of paracetamol by potentiometric method are represented in Table 2. It is found that paracetamol can be easily titrated by potentiometric method in nonaqueous media like glacial acetic acid with perchloric acid and in pyridine, dimethylformamide and ethyl alcohol with sodium ethoxide. Good inflection point is obtained, results are reproducible and recovery is nearly $100 \%$.

\section{Acid-base reactions of paracetamol in nonaqueous solvents}

Many acids or bases such as paracetamol that are too weak for determination in water become susceptible to titration in appropriate nonaqueous solvents. The major considerations in the choice of a solvent for acidimetric reactions are its acidity and basicity, its dielectric constant, and the physical solubility of a solute. Acidity is

\begin{tabular}{|c|c|c|c|}
\hline \multicolumn{4}{|c|}{ Potentiometric Titration of Paracetamol in glacial acetic acid with $0.1 \mathrm{~N} \mathrm{HClO}_{4}$ in glacial acetic acid, using platinum - calomel electrodes } \\
\hline Volume of $0.1 \mathrm{~N} \mathrm{HCIO} 4, \mathrm{ml}$ & Potential, Volts & Volume of $0.1 \mathrm{~N} \mathrm{HCIO} 4, \mathrm{ml}$ & Potential, Volts \\
\hline 5 & 0.49 & 15 & 0.525 \\
\hline 5.5 & 0.49 & 16 & 0.525 \\
\hline 6 & 0.49 & 17 & 0.53 \\
\hline 7 & 0.49 & 18 & 0.53 \\
\hline 8 & 0.495 & 19 & 0.53 \\
\hline 9 & 0.5 & 20 & 0.535 \\
\hline 10 & 0.5 & 21 & 0.535 \\
\hline 11 & 0.504 & 22 & 0.535 \\
\hline 12 & 0.514 & 23 & 0.535 \\
\hline 13 & 0.514 & 24 & 0.535 \\
\hline 14 & 0.525 & 25 & 0.535 \\
\hline \multicolumn{4}{|c|}{ Potentiometric Titration of Paracetamol in pyridine with $0.075 \mathrm{~N}$ soldium ethoxide in ethyl alcohol, using platinum - calomel electrodes } \\
\hline Volume of $0.075 \mathrm{~N} \mathrm{C} 2 \mathrm{H} 5 \mathrm{ONa}, \mathrm{ml}$ & Potential, Volts & Volume of $0.075 \mathrm{~N} \mathrm{C2H5ONa,} \mathrm{ml}$ & Potential, Volts \\
\hline 4 & 0.22 & 15 & 0.279 \\
\hline 5 & 0.22 & 16 & 0.293 \\
\hline 6 & 0.225 & 17 & 0.305 \\
\hline 7 & 0.225 & 18 & 0.314 \\
\hline 8 & 0.232 & 19 & 0.317 \\
\hline 9 & 0.232 & 20 & 0.317 \\
\hline 10 & 0.232 & 21 & 0.326 \\
\hline 11 & 0.239 & 22 & 0.326 \\
\hline 12 & 0.243 & 23 & 0.326 \\
\hline 13 & 0.249 & 24 & 0.326 \\
\hline 14 & 0.26 & 25 & 0.326 \\
\hline \multicolumn{4}{|c|}{ Potentiometric Titration of Paracetamol in dimethylformamide with $0.075 \mathrm{~N}$ sodium ethoxide in ethyl alcohol, using platinum-calomel electrodes. } \\
\hline Volume of $0.075 \mathrm{~N} \mathrm{C2H5ONa,} \mathrm{ml}$ & Potential, Volts & Volume of $0.075 \mathrm{~N} \mathrm{C2H} 5 \mathrm{ONa}, \mathrm{ml}$ & Potential, Volts \\
\hline 2 & 0.22 & 17 & 0.262 \\
\hline 3 & 0.224 & 18 & 0.273 \\
\hline 4 & 0.227 & 19 & 0.28 \\
\hline 5 & 0.227 & 20 & 0.282 \\
\hline 6 & 0.227 & 21 & 0.285 \\
\hline 7 & 0.227 & 22 & 0.288 \\
\hline 8 & 0.227 & 23 & 0.291 \\
\hline 9 & 0.227 & 24 & 0.291 \\
\hline 10 & 0.223 & 25 & 0.291 \\
\hline 11 & 0.223 & 26 & 0.291 \\
\hline
\end{tabular}




\begin{tabular}{|c|c|c|c|}
\hline 12 & 0.223 & 27 & 0.291 \\
\hline 13 & 0.226 & 28 & 0.291 \\
\hline 14 & 0.231 & 29 & 0.291 \\
\hline 15 & 0.235 & 30 & 0.291 \\
\hline 16 & 0.247 & & \\
\hline \multicolumn{4}{|c|}{ Potentiometric Titration of Paracetamol in Pyridine with $0.09 \mathrm{~N}$ sodium ethoxide in ethyl alcohol. } \\
\hline Volume of $0.09 \mathrm{~N} \mathrm{C2H} 5 \mathrm{ONa}, \mathrm{ml}$ & Potential, Volts & Volume of $0.09 \mathrm{~N} \mathrm{C2H} 5 \mathrm{ONa}, \mathrm{ml}$ & Potential, Volts \\
\hline 3 & 0.385 & 15 & 0.415 \\
\hline 4 & 0.385 & 16 & 0.415 \\
\hline 5 & 0.385 & 17 & 0.42 \\
\hline 6 & 0.385 & 18 & 0.42 \\
\hline 7 & 0.385 & 19 & 0.42 \\
\hline 8 & 0.395 & 20 & 0.42 \\
\hline 9 & 0.395 & 21 & 0.42 \\
\hline 10 & 0.395 & 22 & 0.42 \\
\hline 11 & 0.4 & 23 & 0.42 \\
\hline 12.1 & 0.405 & 24 & 0.42 \\
\hline 13 & 0.415 & 25 & 0.42 \\
\hline 14 & 0.415 & & \\
\hline \multicolumn{4}{|c|}{ Potentiometric Titration of Paracetamol in dimethyl formamide with $0.09 \mathrm{~N}$ sodium ethoxide in ethylalcohol. } \\
\hline Volume of $0.09 \mathrm{~N} \mathrm{C2H} 5 \mathrm{ONa}, \mathrm{ml}$ & Potential, Volts & Volume of $0.09 \mathrm{~N} \mathrm{C2H} 5 \mathrm{ONa}, \mathrm{ml}$ & Potential, Volts \\
\hline 0.5 & 0.395 & 13 & 0.415 \\
\hline 1 & 0.395 & 14 & 0.42 \\
\hline 2 & 0.395 & 15 & 0.42 \\
\hline 3 & 0.395 & 16 & 0.42 \\
\hline 4 & 0.395 & 17 & 0.42 \\
\hline 5 & 0.395 & 18 & 0.42 \\
\hline 6 & 0.395 & 19 & 0.42 \\
\hline 7 & 0.395 & 20 & 0.42 \\
\hline 8 & 0.4 & 21 & 0.42 \\
\hline 9 & 0.4 & 22 & 0.42 \\
\hline 10 & 0.4 & 23 & 0.42 \\
\hline 11 & 0.405 & 24 & 0.42 \\
\hline 12 & 0.405 & 25 & 0.42 \\
\hline \multicolumn{4}{|c|}{ pH-metric Titration of Paracetamol in ethyl alcohol with $0.083 \mathrm{~N}$ sodium ethoxide in ethylalcohol. } \\
\hline Volume of $0.083 \mathrm{~N} \mathrm{C2H} 5 \mathrm{ONa}, \mathrm{ml}$ & pH & Volume of $0.083 \mathrm{~N} \mathrm{C2H} 5 \mathrm{ONa}, \mathrm{ml}$ & Potential, Volts \\
\hline 4 & 12 & 14.5 & 13.3 \\
\hline 5 & 12.1 & 15 & 13.4 \\
\hline 6 & 12.15 & 16 & 13.5 \\
\hline 7 & 12.25 & 17 & 13.6 \\
\hline 7.5 & 12.3 & 18 & 13.65 \\
\hline 8 & 12.4 & 19 & 13.7 \\
\hline 9 & 12.5 & 20 & 13.75 \\
\hline 10 & 12.6 & 21 & 13.75 \\
\hline 11 & 12.7 & 22 & 13.8 \\
\hline 12 & 12.8 & 23 & 13.8 \\
\hline 13 & 12.9 & 24 & 13.8 \\
\hline 14 & 13.2 & 25 & 13.85 \\
\hline
\end{tabular}

Table 1: The acid-base titrations of paracetamol in nonaqueous solvents. 


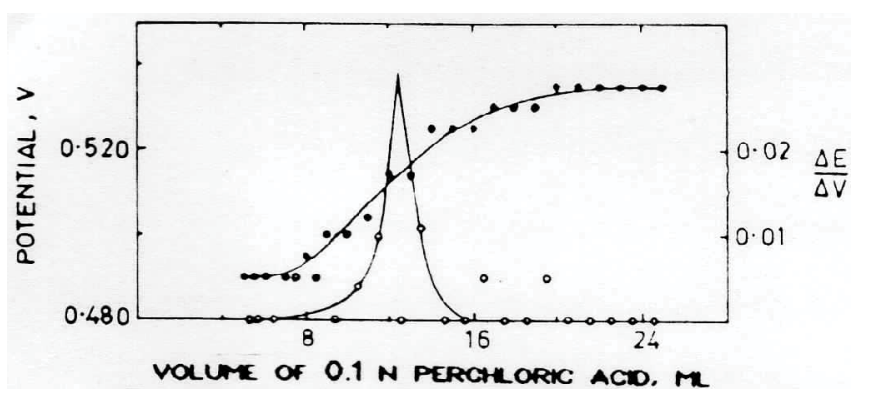

Figure 1: Potentiometric Titration curves for Paracetamol in glacial acetic acid with $0.1 \mathrm{~N} \mathrm{HClO}_{4}$ in glacial acetic acid, using platinum - calomel electrodes.

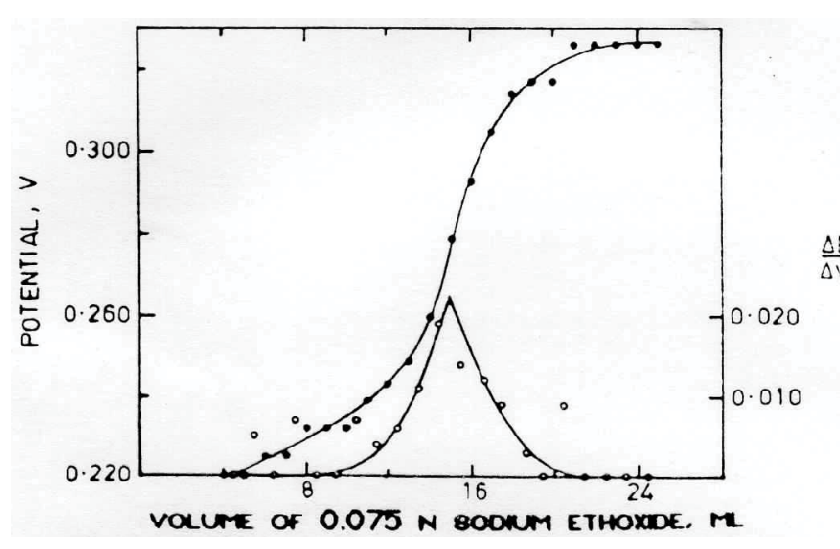

Figure 2: Potentiometric Titration curves for Paracetamol in pyridine with $0.075 \mathrm{~N}$ soldium ethoxide in ethyl alcohol, using platinum - calomel electrodes.

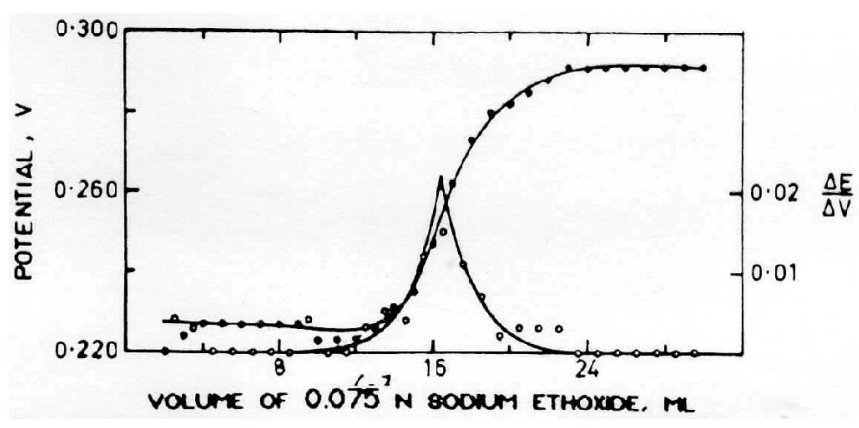

Figure 3: Potentiometric Titration curves for Paracetamol in dimethylformamide with $0.075 \mathrm{~N}$ sodium ethoxide in ethyl alcohol, using platinum-calomel electrodes.

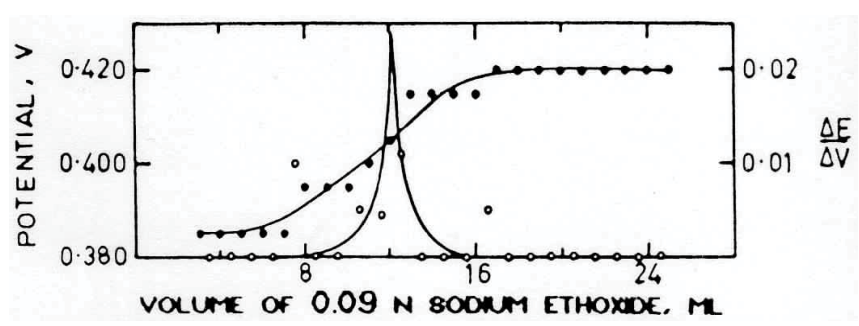

Figure 4: Potentiometric Titration curves for Paracetamol in Pyridine with $0.09 \mathrm{~N}$ sodium ethoxide in ethyl alcohol.

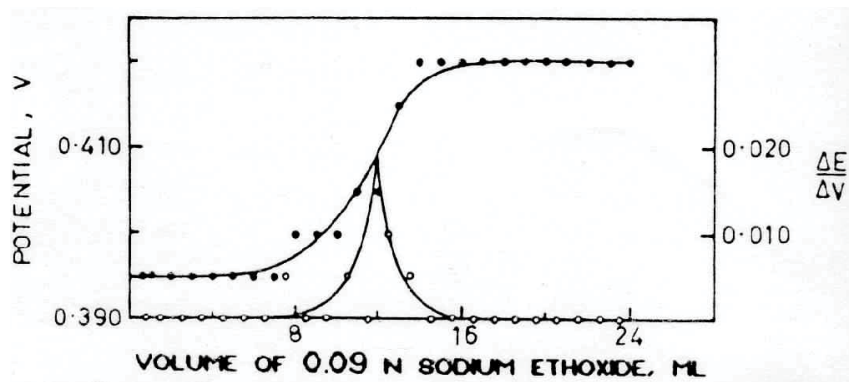

Figure 5: Potentiometric Titration curves for Paracetamol in dimethyl formamide with $0.09 \mathrm{~N}$ sodium ethoxide in ethylalcohol.

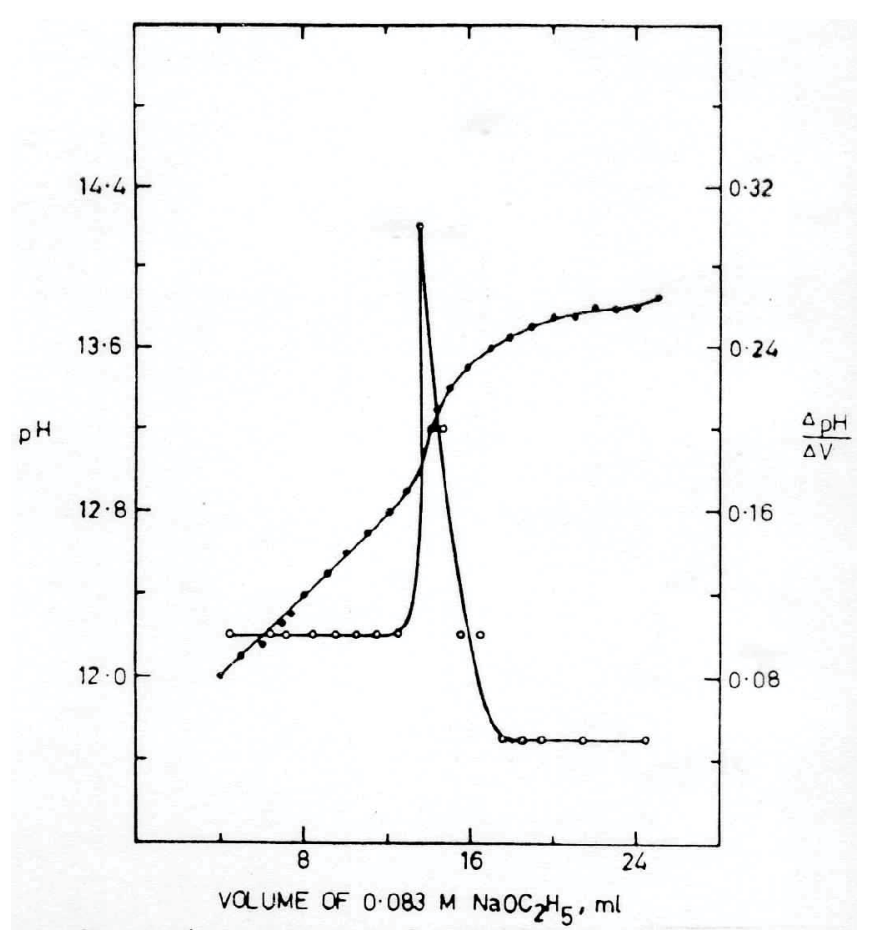

Figure 6: $\mathrm{pH}$-metric Titration curves for Paracetamol in ethyl alcohol with $0.083 \mathrm{~N}$ sodium ethoxide in ethyl alcohol.

important because it determines to a large extent whether or not a weak acid can be titrated in the presence of a relatively high concentration of solvent molecules. Paracetamol, for example, cannot be titrated as an acid in aqueous solution because water is too acid and present in too high a concentration to permit the p-oxyacetanilide ion to be formed stoichiometrically by titration with a base. In other words the intrinsic basic strength of the p-oxyacetanilide ion and hydroxide ions are not sufficiently different for the reaction:<smiles>CC(=O)Nc1ccc([O-])cc1</smiles>

In less acid solvents, such as dimethylformamide or pyridine, this titration can be carried out readily with a stronger basic titrant, the alkoxide ion: 


\begin{tabular}{|c|c|c|c|c|c|c|c|}
\hline \multirow{2}{*}{$\begin{array}{l}\text { S No } \\
1\end{array}$} & \multirow{2}{*}{$\begin{array}{l}\text { Solvent } \\
\text { Glacial acetic acid }\end{array}$} & \multirow{2}{*}{$\begin{array}{l}\text { Titrant } \\
0.1 \mathrm{~N} \mathrm{HClO} 4 \text { in acetic acid }\end{array}$} & \multirow{2}{*}{$\begin{array}{l}\text { Electrode system } \\
\text { Platinum - Calomel }\end{array}$} & \multirow{2}{*}{\begin{tabular}{|l|} 
Inflection \\
Point
\end{tabular}} & \multirow{2}{*}{$\begin{array}{l}\text { Weight of } \\
\text { Tablet } \\
0.6 \\
\end{array}$} & \multicolumn{2}{|c|}{$\begin{array}{l}\text { Amount of Paracetamol } \\
\text { per Tablet, } g\end{array}$} \\
\hline & & & & & & 0.5 & 0.5669 \\
\hline 2 & Pyridine & $0.075 \mathrm{~N} \mathrm{C} 2 \mathrm{H} 5 \mathrm{ONa}$ in ethyl alcohol & Platinum - Calomel & 15 & 0.5915 & 0.5 & 0.5029 \\
\hline 3 & Dimethyl formamide & $0.075 \mathrm{~N} \mathrm{C} 2 \mathrm{H} 5 \mathrm{ONa}$ in ethyl alcohol & Platinum - Calomel & 16.5 & 0.5965 & 0.5 & 0.5579 \\
\hline 4 & Pyridine & $0.09 \mathrm{~N} \mathrm{C} 2 \mathrm{H} 5 \mathrm{ONa}$ in ethyl alcohol & Glass - Calomel & 12.5 & 0.6097 & 0.5 & 0.4997 \\
\hline 5 & Dimethyl formamide & $0.09 \mathrm{~N} \mathrm{C} 2 \mathrm{H} 5 \mathrm{ONa}$ in ethyl alcohol & Glass - Calomel & 12 & 0.6132 & 0.5 & 0.5 \\
\hline 6 & Ethyl alcohol & $0.083 \mathrm{~N} \mathrm{C} 2 \mathrm{H} 5 \mathrm{ONa}$ in ethyl alcohol & Glass - Calomel & 13.5 & 0.5875 & 0.5 & 0.4975 \\
\hline
\end{tabular}

Note: Amount of Paracetamol per tablet,

$\mathrm{g}=\frac{\text { Inflection Point } \times \text { Mol. wt. of Paracetamol } \times \text { Normality of Titrant }}{1000 \times 1} \times \frac{\text { Weight of Tablet }}{\text { Weight of Tablet taken }}$

Table 2: Analysis of crocin (duphar) paracetamol tablet by potentiometric acid - base titration methods.<smiles>CC(=O)Nc1ccc([O-])cc1NC(C)=O</smiles>

Acidic properties of solvent such as acetic acid produce a pronounced levelling effect on the weak base (p-hydroxyacetanilide) and thus it gets converted into strong base which then can be titrated with strong acid. The titrant is a solution of perchloric acid in glacial acetic acid which has been standardized with potassium hydrogen phthalate. In an analogous fashion, basic solvents enhance the properties of weak acid (p-oxyacetanilide). It produce distinctive end point in dimethylformamide. The titrant is sodium ethoxide. The electrode systems vary with the solvent employed. The platinumcalomel electrode system is suitable where the solvent is glacial acetic acid in this case perchloric acid in glacial acetic acid is the titrant while the glass-calomel electrode system is suitable where the solvent is either pyridine, and alcohol or dimethylformamide, the titrant consists of sodium ethoxide. Acid-Base reaction involved in case of paracetamol while titrating with perchloric acid/sodium ethoxide can be represented as follows.

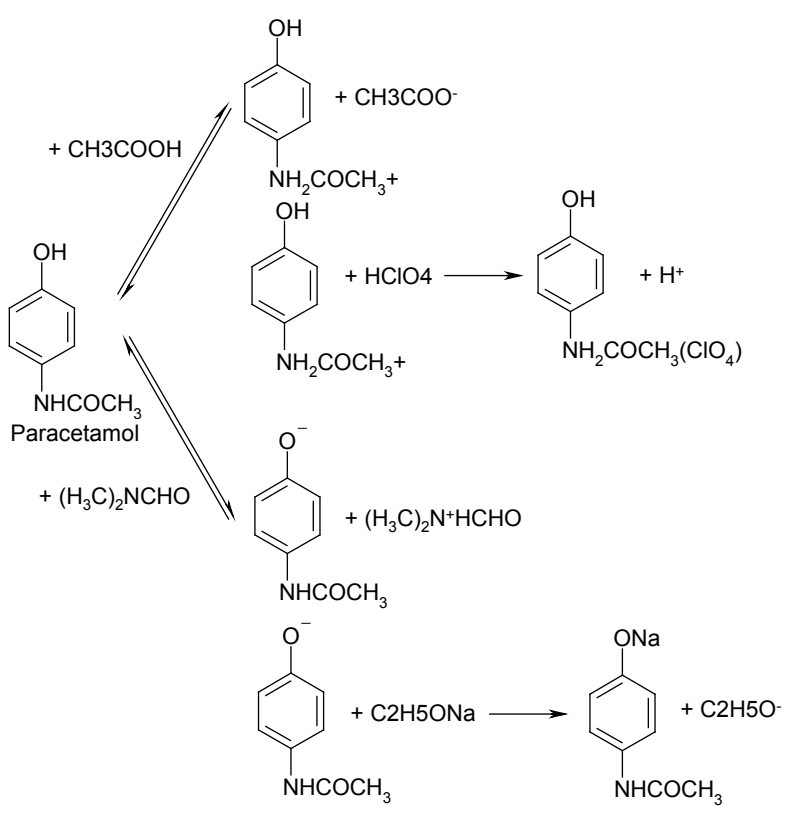

\section{Conclusion}

Based on potentiometric studies of paracetamol it is concluded that the acid-base titration of paracetamol is rapid and reproducible, and permits its determination in medicinal sample. The electrode systems vary with the solvent employed. The platinum-calomel electrode system is suitable where the solvent is glacial acetic acid in this case perchloric acid in glacial acetic acid is the titrant while the glass-calomel electrode system is suitable where the solvent is either pyridine, an alcohol or dimethyiformamide, the titrant consists of sodium ethoxide in ethyl alcohol.

\section{References}

1. Reynolds JEF (1996) Martindale the Extra Pharmacopoeia. Pharmaceutical Press, London 31: 27-28.

2. The United States Pharmacopoeia (2000) US Pharmacopeial Convention, Rockville, MD, USA. 24th Revision. pp: 17-39.

3. British Pharmacopoeia (1998) Compact Disc, Version 2. The Stationery Oce Ltd., Norwich.

4. European Pharmacopoeia (1997) Convention on the Elaboration of a European Parmacopoeia (European Treaty Series No. 50), Strasbourg. 3rd edn. pp: 748749 .

5. Lau OW, Luk SF, Cheung YM (1989) Simultaneous determination of ascorbic acid, caffeine and paracetamol in drug formulations by differential-pulse voltammetry using a glassy carbon electrode. Analyst 114: 1047-1051.

6. El-Obeid HA, Al-Badr AA (1985) Analytical Proles of Drug Substances American Pharmaceutical Association 14: 551-596.

7. Chan HK, Grant DJW (1989) Influence of compaction on the intrinsic dissolution rate of modified acetaminophen and adipic acid crystals. Int J Pharm 57: 117-124.

8. Erk N, Onur F (1997) Simultaneous Determination of Analgine and Paracetamol in Tablets by Spectrophotometric Methods. Anal Lett 30: 1201-1210.

9. Doğan HN (1996) Simultaneous determination of acetaminophen, dipyrone and caffeine in pharmaceutical preparations by the absorbance ratio technique. Pharmazie 51: 773-774.

10. Kahela P, Laine E, Anttila M (1987) A Comparison of the Biovailability of Paracetamol from a Fatty and a Hydrous Suppository Base and the Effect of Storage on the Absorption in Man. Drug Dev Ind Pharm 13: 213-224.

11. Suzen S, Akay C, Tart S, Erdol RS, Onal A, et al. (1998) J Faculty of Pharm Ankara Univ 27: 93-100.

12. Sisco WR, Rittenhouse CT, Everhart LA, McLaughlin AM (1986) Simultaneous high-performance liquid chromatographic stability-indicating analysis of acetaminophen, codeine phosphate and sodium benzoate in elixirs. J Chromatogr 354: 355-366.

13. Hossain M, Ayres JW (1996) Relative bioavailability of a novel sustainedrelease acetaminophen molded tablet. Int J Pharm 133: 223-235.

14. Ali HM, Homeida MMA, Ford J, Truman CA, Roberts CJC, et al. (1988) Paracetamol bioavailability from an elixir, a suspension and a new alcohol-free liquid dosage form in humans. Int J Pharm 42: 155-159.

15. Yuen KH, Peh KK, Quah YL, Chan KL (1997) A Novel Simultaneous HPLC Assay for Serum Paracetamol and Sulfapyridine as Markers of Gastric Emptying and Orocecal Transit. Drug Dev Ind Pharm 23: 225-228.

16. Orsi DD, Gagliardi L, Bolasco A, Tonelli D (1996) Simultaneous determination of triprolidine, pseudoephedrine, paracetamol and dextromethorphan by HPLC. Chromatographia 43: 496-500. 
17. Bergh JJ, Lotter AP (1984) A Stability-Indicating Gas-Liquid Chromatographic Method for the Determination of Acetaminophen and Aspirin in Suppositories. Drug Dev Ind Pharm 10: 127-136.

18. Chatten LG, Orbeck CK (1964) Effect of electrophilic and electrodotic groups on the titration of amides and other weak bases. J Pharm Sci 53: 1306-1308.

19. Keim AN, Sterescu M (1960) Rev Chim 11: 49.

20. Wimer DC (1958) Anal Chem 30: 77.

21. Mackenzie HAE, Winter ERS (1948) Trans Faraday Soc 44: 243.

22. Burton H, Praill PFG (1950) Acylation reactions catalysed by strong acids. Part I. Evidence for the existence of acetylium (the acetyl cation), $\left(\mathrm{CH}_{3} \cdot \mathrm{CO}\right)^{+}$, in solutions of concentrated aqueous perchloric acid in acetic anhydride. $\mathrm{J}$ Chem Soc 1203-1206.
23. Burton H, Praill PFG (1950) Acylation reactions catalysed by strong acids. Part II. "Acetyl perchlorate" as a C-acetylating agent. J Chem Soc 2034-2038.

24. Mackenzie HAE, Winter ERS (1948) Kinetic studies in the solvents acetic acid and acetic anhydride. Part II. The Thiele acetylation of benzoquinone and toluquinone (experimental). Trans Faraday Soc 44: 171-181.

25. Mackenzie HAE, Winter ERS (1948) Kinetic studies in the solvents acetic acid and acetic anhydride. Part I. Properties of the solvo-system. Trans Faraday Soc 44: 159-171.

26. Levent M (2002) HPLC Method for the Analysis of Paracetamol, Caffeine and Dipyrone. Turk J Chem 26: 521- 528. 